\title{
PENERAPAN MODEL PROBLEM BASED LEARNING UNTUK MENINGKATKAN BERPIKIR KRITIS SISWA KELAS 5 PADA MATA PELAJARAN PKN DI SD MUHAMMADIYAH KAUMAN TAHUN 2016/ 2017
}

\author{
Tri Siwi Septiana \\ M. Ragil Kurniawan \\ PGSD FKIP Universitas Ahmad Dahlan \\ trisiwiseptiana@gmail.com
}

\begin{abstract}
This study aims to improve students' critical thinking skills in Civics in 5th grade students of SD Muhammadiyah Kauman, Yogyakarta using Problem Based Learning model. This research is a Classroom Action Research (PTK). The subjects of the study were 5th grade students of B1 SD Muhammadiyah Kauman. The object of research is the whole process and the results of learning Civics with the application of Problem Based Learning model. This research was conducted at SD Muhammadiyah Pakel Yogyakarta in April until May 2017. Data collection techniques used were observation, diary, interview and test. Data analysis technique is done descriptively qualitative. This research was conducted in 2 cycles by applying problem based learning model. The learning steps that were implemented were changes in the delivery of the subject matter, the students analyzed the problem, the formation of the discussion group with the grouping of students based on their achievement, the students in group for discussion, the group members delivered the discussion result in front of the class.

The results showed that the critical thinking ability of the 5th grade students of B1 SD Muhammadiyah Kauman, Yogyakarta increased after the use of Problem Based Learning model in Civics learning with the subject matter of the example of central and regional legislation. This improvement is evident in the improvement of students' critical thinking skill test result from $12.90 \%$ pretreatment score to $51.61 \%$ (enough) in cycle I and increased to $70.96 \%$ (good) in cycle II. The results of activity observations related to students' critical thinking skills are increased among others: active students in learning, students more freely in finding and collecting desired information, and students also have more opportunities to learn with friends.
\end{abstract}

Keywords: model of problem based learning, critical thinking ability of students, Civics

\begin{abstract}
ABSTRAK
Penelitian merupakan Penelitian Tindakan Kelas (PTK). Subjek penelitian adalah siswa kelas 5 B1 SD Muhammadiyah Kauman. Objek penelitian adalah keseluruhan proses dan hasil pembelajaran PKn dengan penerapan model Problem Based Learning. Penelitian ini dilaksanakan di SD Muhammadiyah Pakel Yogyakarta pada bulan April sampai bulan Mei 2017. Teknik pengumpulan data yang digunakan adalah observasi, catatan harian, wawancara dan tes. Teknik analisis data dilakukan secara deskriptif kualitatif. Penelitian ini dilaksanakan dalam 2 siklus dengan menerapkan model problem based learning.
\end{abstract}


Langkah--langkah pembelajaran yang dilaksanakan yaitu perubahan dalam penyampaian materi pelajaran, siswa menganalisis permasalahan, pembentukan kelompok diskusi dengan pengelompokan siswa yang didasari dari prestasinya, siswa berkelompok untuk berdiskusi, anggota kelompok menyampaikan hasil diskusi di depan kelas.

Hasil penelitian menunjukkan bahwa kemampuan berpikir kritis siswa kelas 5 B1 SD Muhammadiyah Kauman, Yogyakarta meningkat setelah digunakannya model Problem Based Learning dalam pembelajaran PKn dengan materi pokok contoh peraturan perundang-undangan tingkat pusat dan daerah. Peningkatan ini terbukti pada peningkatan hasil tes kemampuan berpikir kritis siswa dari skor rata-rata pratindakan sebesar $12,90 \%$ menjadi 51,61\% (cukup) pada siklus I dan meningkat menjadi 70,96\% (baik) pada siklus II. Hasil observasi aktifitas yang berhubungan dengan kemampuan berpikir kritis siswa meningkat antara lain: siswa aktif dalam pembelajaran, siswa lebih leluasa dalam mencari dan mengumpulkan informasi yang diinginkan, dan siswa juga memiliki lebih banyak kesempatan untuk belajar bersama teman.

Kata kunci : model problem based learning, kemampuan berpikir kritis siswa, PKn

\section{PENDAHULUAN}

Pendidikan Kewarganegaraan (PKn) merupakan mata pelajaran yang membentuk siswa menjadi warganegara yang baik, sehingga diperlukanmya penanaman nilai agar terbentuk karakter tersebut. Pendidikan sekarang ini dituntut memiliki kualitas kelulusan yang baik. Salah satu poin yaitu membuat standar kelulusan. Standar kelulusan yang dibuat dari tahun ke tahun selalu berubah dan semakin lama semakin tinggi. Dengan demikian mata pelajaran PKn dengan mencoba menyelesaikan masalah saat proses pembelajaran berlangsung. Dengan melibatkan siswa untuk berperan aktif dalam proses pembelajaran siswa akan lebih mudah menyelesaikan masalah pembelajaran, agar mendapat pengalaman dan mampu memahami materi yang sedang di ajarkan. Menyelesaikan atau mencari tahu mengenai informasi baru yang didapat secara langsung akan mudah melekat diingatan siswa, dibandingkan dengan mendengarkan penjelasan dari orang lain yang dipelajari tidak cukup sebatas pada pemahaman konsep.

Menurut Fathurrohman (2008), komponen penting yang hendak dikembangkan dalam pembelajaran PKn adalah membentuk warga negara yang cerdas (memiliki pengetahuan warga negara), berkarakter, serta membentuk warga negara yang terampil dalam berpikir kritis. Oleh karena itu, diperlukan upaya agar siswa terlibat secara langsung dan merasa terkesan dalam mengikuti pembelajaran PKn. Dari beberapa komponen tersebut perlu diketahui bahwa berpikir kritis penting diterapkan, bukan hanya menghafal teori saja yang mudah dilupakan akan tetapi mampu menganalisis dan memahami maknanya serta memperoleh keterampilan yang berguna bagi kehidupannya dilingkungan masyarakat. Menurut Tinio (dalam Wahyuni, 2011), salah satu ketrampilan yang dibutuhkan untuk menghadapi tantangan di masa yang akan datang adalah keterampilan berpikir tingkat tinggi (higher order thinking) atau sering disebut keterampilan berpikir kritis (critical thingking). Menyadari pentingnya mengembangkan kemampuan berpikir kritis sejak sekolah dasar maka diperlukan adanya pembelajaran yang lebih banyak melibatkan proses pembelajaran berpikir.

Permasalahan dunia pendidikan pada kenyataannya hampir tidak pernah berakhir, salah satunya dalam pembelajaran PKn. Pembelajaran yang terkesan kaku, kurang fleksibel, berisi hafalan, dan membosankan selama ini terus berjalan sehingga berpikir kritis yang merupakan bagian dari berpikir tingkat tinggi menjadi terabaikan (Fathurrohman, 2008). Semakin perlunya model pembelajaran untuk merubah keberhasilan 
dalam pembelajaran PKn. Hal ini mengindikasikan guru dirasa perlu berperan dalam mengembangkan model pembelajaran untuk meningkatkan tingkat perkembangan berpikir kritis siswa. Guru perlu mendorong siswa terlibat aktif dalam berbagai proses pembelajaran. Proses tersebut meliputi diskusi, bertanya, menjawab pertanyaan, berpikir secara kritis, menjelaskan setiap jawaban yang diberikan, serta mengajukan alasan untuk setiap jawaban yang diajukan. Keterampilan berpikir kritis tidak semata-mata dimiliki peserta didik sehingga perlunya latihan terbimbing. Taraf kemampuan berpikir kritis usia sekolah dasar dalam perkembangan kognitif seharusnya sudah mampu berpikir secara kritis dalam tahap sederhana, tentu berbeda dengan perkembangan usia siswa SMP dan SMA yang mencakup seluruh indikator berpikir kritis (Ngalimun, 2014).

Kondisi yang terjadi di lapangan belum seluruhnya siswa dapat berpikir kritis. Pemilihan model pembelajaran yang tepat dapat membantu memperjelas materi akan yang disampaikan. Berdasarkan hasil observasi yang dilakukan di SD Muhammadiyah Kauman pada guru kelas 5, terdapat beberapa masalah yang muncul salah satu diantaranya menunjukkan rendahnya berpikir kritis siswa dalam proses pembelajaran PKn. Hal ini terlihat, siswa tidak mampu merumuskan pokok-pokok permasalahan, tidak mampu berpendapat sesuai dengan materi pelajaran, dan tidak dapat menyelesaikan soal dengan baik dan benar.

Masalah lain yang muncul seperti model pembelajaran belum sesuai dengan karakteristik siswa. Pembelajaran berpusat pada guru (teacher centered), siswa hanya duduk, mendengarkan, mencatat dan menghafal dalam proses KBM. Kondisi yang demikian akan membuat siswa jenuh dan tidak tertarik dalam pembelajaran. Kegiatan yang berjalan menekankan penguasaan materi sebanyak-banyaknya sehingga siswa menganggap materi pembelajaran $\mathrm{PKn}$ hanya untuk dihafalkan, tidak untuk dimengerti dan dikembangkan.

Dalam kondisi lain separuh lebih dari jumlah siswa dikelas tersebut tidak melakukan sesuatu untuk mengembangkan dirinya dan rasa ingin tahu siswa cenderung rendah terhadap materi yang diajarkan. Hal tersebut dapat dilihat dari hasil pengamatan dikelas, siswa merasa cuek ketika mengikuti proses pembelajaran. Siswa lebih asik bermain sendiri ketika proses pembelajaran berlangsung, sehingga ketika ditanya siswa sulit menjawab. Apabila hal tersebut berjalan terus menerus maka dapat mengakibatkan daya berpikir siswa menjadi rendah dan membuat siswa tidak mampu mengembangkan dirinya untuk lebih kritis dalam berpikir. Jika dilihat dari hasil ulangan harian sebagian masih dibawah Kriteria Ketuntasan Minimal (KKM) yang telah ditetapkan yaitu sebesar 70. Dari 31 siswa hanya $12,90 \%$ (4 siswa) yang sudah memenuhi KKM, sedangkan 87,10\% (27 siswa) belum memenuhi KKM.

Permasalahan tersebut menunjukkan bahwa perlu adanya perbaikan mengenai proses pembelajaran PKn di sekolah dasar kelas 5. Model problem based learning dirasa tepat untuk mengembangkan siswa berpikir kritis dalam menemukan dan memecahkan masalah. Model problem-based learning mengembangkan bagaimana masalah yang dibahas berkaitan dengan dunia nyata. Dengan penggunaan model pembelajaran ini siswa belajar mengasah ketrampilan berpikir kritis untuk memperoleh pengetahuan dari materi pelajaran (Daryanto, 2015: 64). Oleh sebab itu, model problem based learning dapat menjadi salah satu solusi untuk mendorong siswa berpikir dan bekerja ketimbang menghafal dan bercerita (Trianto, 2010: 94). Dalam penggunaan model pembelajaran ini, akan menyajikan tugas individu/ perseorangan dan kelompok. Tugas kelompok yang akan diberikan berupa latihan-latihan soal yang harus dikerjakan secara berkelompok. Model pembelajaran dimulai dengan menyajikan permasalahan nyata yang penyelesaiannya membutuhkan kerjasama diantara siswa-siswa. Berdasarkan permasalahan latar belakang 
yang telah diuraikan, peneliti melakukan penelitian tentang Penerapan Model Problem Based Learning Untuk Meningkatkan Berpikir Kritis Siswa Kelas 5 Pada Mata Pelajaran PKn di SD Muhammadiyah Kauman Tahun 2016/ 2017.

Pendidikan Kewarganegaraan (PKn) adalah mata pelajaran wajib untuk jenjang sekolah dasar. Menurut Tim Dosen PKn-UMC Syarifuddin et,al. (2014). Mata pelajaran PKn merupakan mata pelajaran yang memfokuskan pada pembentukan warga negara yang memahami dan mampu melaksanakan hak-hak dan kewajibannya untuk menjadi warga negara yang cerdas, terampil, dan berkarakter yang diamanatkan oleh UUD 1945. Terampil yang diharapkan yaitu terampil dalam kemampuan berpikir kritis serta membawa siswa mengenal, memilih, dan memecahkan masalah sesuai dengan karakteristik model pembelajaran PKn di sekolah dasar. Menurut Tim dosen PKn-UMC Syarifuddin et,al.(2014), Salah satu SK dan KD yang dipergunakan sebagai berikut:

Tabel 1 SK \& KD Kelas V

Standar Kompetensi Kompetensi Dasar

2. Memahami peraturan perundang-undangan tingkat pusat dan daerah

2.1Menjelaskan pengertian dan pentingnya peraturan perundang-undangan tingkat pusat dan daerah.

2.2Memberikan contoh peraturan perundang-undangan tingkat pusat dan daerah, seperti pajak, anti korupsi, lalu lintas, larangan merokok.

Siswa harus memiliki minimal Kompetensi Dasar dalam rangka menguasai SK mata pelajaran tertentu. Menurut Fathurrohman \& Wuryandani (2011), mata pelajaran PKn bertujuan agar peserta didik memiliki kemampuan sebagai berikut: (1)Berpartisipasi secara aktif dan bertanggung jawab dan bertindak secara cerdas dalam kegiatan bermasyarakat, berbangsa, dan bernegara, serta anti-korupsi. (2) Berpikir secara kritis, rasional, dan kreatif dalam menanggapi isu kewarganegaraan. (3) Berkembang secara positif dan demokratis untuk membentuk diri berdasarkan karakter-karakter masyarakat Indonesia agar dapat hidup bersama dengan bangsa-bangsa lainnya. (4) Berinteraksi dengan bangsa-bangsa lain dalam percaturan dunia dengan memanfaatkan teknologi informasi dan komunikasi.

PKn melalui pengetahuan yang diberikan di sekolah diharapkan melahirkan generasi muda yang menekankan pada perkembangan dan membina warga negara yang berpikir secara kritis, rasional, dan kreatif memiliki sikap demokratis dan bertanggung jawab. Sebagaimana warga negara yang sanggup melaksanakan hak dan kewajibannya dalam kehidupan berbangsa dan bernegara.

Cara yang sistematis diperlukan dalam mengkomunikasikan isi pelajaran kepada siswa untuk mencapai kompetensi dasar tertentu. Pengajaran melalui pemecahan masalah terdiri atas lima langkah menurut Hamid Hasan (dalam Solihatin, 2013) yang menyatakan bahwa:

1. Identifikasi masalah

Langkah awal yang penting, karena gagal mengidentifikasi masalah berakibat kegagalan dalam upaya penyelesaiannya. Kegiatan identifikasi dapat dilakukan guru secara langsung menyajikan masalah atau siswa sendiri yang merumuskan masalah.

2. Pengembangan alternatif

Kelas dapat dikelompokkan beberapa group membahas alternatif suatu masalah dan pengembangan dapat dilakukan dengan penugasan individual.

3. Pengumpulan data untuk menguji alternatif

Data dikumpulkan dari berbagai sumber yang kemudian dikelompokkan berdasarkan alternatif.

4. Penguji alternatif 
Melihat kesesuaian data untuk menguji alternatif.

5. Pengambilan keputusan

Mengambil kesimpulan dan dapat kemudian menentukan alternatif mana yang terbaik

Berpikir kritis atau biasa disebut berpikir tingkat tinggi merupakan keterampilan berpikir mengolah segala informasi, observasi dan permasalahan yang didapat, dengan membuat keputusan apa yang harus dilakukan disertai dengan logika. Hal ini membuat berpikir menjadi hal yang dirasa penting terutama dalam proses pembelajaran.

Seseorang dalam berpikir pada dasarnya dilandasi dengan rasa ingin tahu, benar atau salahnya proses berpikir. Berpikir kritis merupakan bagian dari keterampilan atau kemampuan berpikir tingkat tinggi (Alvino (dalam Tim Pusat Studi Pancasila UGM, 2015). Siswa diberikan contoh-contoh kasus cara berpikir yang baik, memberikan masalah yang menuntut berpikir, dan menerapkan keterampilan untuk mengambil keputusan. Oleh karena itu, contoh kasus yang diberikan pada siswa sekolah dasar harus disesuaikan dengan tahap-tahap perkembangan kognitif menurut Ngalimun (2014) yang diuraikan sebagai berikut:

\section{Tabel 2 Tahap-tahap Perkembangan Kognitif}

Tahap Perkira an Usia

\section{Kemampuan-kemampuan Utama}

\begin{tabular}{lll}
\hline Sensorimotor & lahir sampai 2 tahun & Terbentuknya konsep“kepermanenan objek”. \\
\hline Praoperasional & 2 sampai 7 tahun & $\begin{array}{l}\text { Kemampuan menggunakan simbol-simbol } \\
\text { untuk menyatakan objek-objek dunia. }\end{array}$ \\
\hline Operasi konkret & 7 sampai 11 tahun & Kemampuan untuk berpikir secara logis. \\
\hline Operasi formal & $\begin{array}{l}\text { 11 tahun sampai } \\
\text { dewasa }\end{array}$ & Pemikiran abstrak.
\end{tabular}

Indikator berpikir kritis siswa sekolah dasar menurut peneliti apabila memiliki kemampuan antara lain: (1) Mampu merumuskan pokok permasalahan. (2) Mampu mengungkap fakta dengan tepat yang dibutuhkan dalam menyelesaikan suatu masalah. (3) Mampu memilih pendapat atau argumen sesuai dengan kenyataan. (4) Mampu memberikan pendapat dari sudut pandang yang berbeda. (5) Mampu menyelesaikan masalah yang muncul dari suatu pernyataan yang diambil.

Berpikir kritis memiliki ciri-ciri atau kriteria dalam penilaiannya. Untuk mengetahui apakah seseorang tersebut telah berpikir secara kritis atau belum sebenarnya sulit untuk diketahui, karena berpikir kritis merupakan fenomena yang abstrak. Namun demikian, Menurut Tim Pusat UGM (2015), telah menyusun indikator kemampuan berpikir kritis adalah sebagai berikut:

1. Mampu merumuskan pokok-pokok permasalahan, meliputi: mencari jawaban yang jelas dari setiap pertanyaan.

2. Mampu mengungkap fakta yang dibutuhkan dalam menyelesaikan suatu masalah, meliputi: berusaha mengetahui informasi dengan baik, menyebutkan sumber yang memiliki kredibilitas dan tujuan asli yang mendasar.

3. Mampu memilih argumen logis, relevan dan akurat, meliputi: mencari alasan atau argumen, berusaha tetap relevan dengan dengan ide utama, bersikap secara sistimatis dan teratur dengan memperhatikan bagian-bagian dari keseluruhan masalah.

4. Mampu mendeteksi bias berdasarkan pada sudut pandang yang berbeda, meliputi: mencari alternatif jawaban, mengambil sikap ketika ada bukti yang cukup untuk melakukan sesuatu, mencari penjelasan sebanyak mungkin apabila memungkinkan.

5. Mampu menentukan akibat dari suatu pernyataan yang diambil sebagai suatu keputusan, meliputi: memperhatikan situasi dan kondisi secara keseluruhan, bersikap 
Tujuan berpikir kritis adalah untuk menguji pendapat dapat dipertanggungjawabkan hasilnya. Siswa dituntut untuk lebih memahami dan mengerti tentang apa yang mereka pelajari. Berpikir kritis memiliki tujuan awal yakni menyingkap kebenaran dengan menyerang dan menyingkirkan semua yang salah supaya kebenaran akan terlihat (Bono terjemahan Sitompul \& Yamani, 2007). Oleh sebab itu, proses berpikir kritis sangat diperlukan. Berpikir kritis tidak hanya tentang pemikiran tetapi juga pada tahap kompleks apa, mengapa, dan bagaimana proses pemecahannya.

Problem Based Learning merupakan salah satu model pembelajaran yang awal pembelajarannya menyajikan suatu permasalahan untuk memecahkan masalah yang ada agar dapat memberikan kondisi belajar aktif kepada siswa. Tujuannya yaitu megubah pembelajaran dari teacher center menjadi student center, guru hanya sebagai pengarah dan fasilitator. Metode ceramah dari satu arah dari pendidik ke peserta didik hanya sedikit sekali, maka peran fasilitator antara lain adalah mendorong partsipasi siswa, memberikan informasi secukupnya, mengarahkan mereka pada jalur yang tepat, memberikan umpan balik yang tidak negatif, dan menjadi teman yang mendukung (Aspy et al. (dalam Krisanti \& Mulia, 2016). PBL merupakan suatu bentuk peralihan dari paradigma pengajaran menuju paradigma pembelajaran (Barr \& Tagg (dalam Huda, 2013). Dengan kata lain, $P B L$ merupakan proses belajar yang berbasis masalah bukan proses mengajar yang berbasis masalah. Proses belajar yang dimaksud adalah siswa dibiasakan dengan penyajian suatu permasalahan dalam bentuk nyata yang terjadi disekitar lingkungan kehidupannya. Semakin sering berlatih proses belajar akan semakin baik karena siswa dibiasakan mencari sumber informasi sebanyak-banyaknya sehingga akan meningkatkan tingkat berpikir kritis siswa dalam memahami serta menganalisis suatu permasalahan.

$P B L$ tidak hanya sekedar menyelesaikan masalah tetapi siswa mendapatkan pengetahuan dengan mencari sendiri informasi yang mereka butuhkan untuk menyelesaikan permasalahan tersebut dari berbagai sumber. Selain itu mereka dapat bertukar informasi yang didapat satu sama lain antar teman dengan saling bekerja kelompok. Karakteristik problem based learning dimulai dari dihadapkan pada masalah. Masalah yang dihadapkan berkaitan dengan lingkungan nyata siswa. Kepekaan mendorong untuk mencari, memilih dan menentukan pemecahan sesuai dengan kemampuannya.

Adapun karakteristik Problem Based Learning menurut Huda (2014), Sintak operasional Problem Based Learning dapat mencakup antara lain: 1) Pertama-tama siswa disajikan suatu masalah. 2) Siswa mendiskusikan masalah dalam tutorial $P B L$ dalam sebuah kelompok kecil. Mereka berpijak pada pengetahuan sebelumnya. Kemudian mereka mengidentifikasi, menelaah serta mendesain rencana tindakan untuk menyelesaikan masalah. 3) Siswa terlibat dalam studi independen untuk menyelesaikan masalah diluar bimbingan guru. Hal ini biasanya mencakup: perpustakaan, database, website, masyarakat, dan observasi. 4) Siswa kembali pada tutorial $P B L$, lalu saling sharing informasi, melalui peer teaching atau cooperative learning atas masalah tertentu. 5) Siswa menyajikan solusi atas masalah. 6) Siswa mereview apa yang mereka pelajari selama proses pengerjaan selama ini.

Lain halnya dengan Amir (2010) langkah-langkah dalam problem based learning sebagai berikut.

1. Langkah 1: Mengklarifikasi istilah dan konsep yang belum jelas. Tahap awal meliputi memahami, memastikan, dan menyamakan cara memandang konsep dari permasalahan.

2. Langkah 2: Merumuskan masalah

Fenomena masalah diperjelas apakah mengenai permasalahan nyata atau hubungan yang masih belum nyata. 
3. Langkah 3: Menganalisis masalah. Anggota saling mengeluarkan pengetahuannya untuk berdiskusi menyelesaikan permasalahan dari berbagai sumber.

4. Langkah 4: Menata gagasan dan secara sistematis menganalisisnya dengan dalam. Memilah sesuatu dan dilihat keterkaitannya dengan dikelompokkan, mana yang saling bertentangan dan lain sebagainya.

5. Langkah 5: Memformulasikan tujuan pembelajaran.

Merumuskan tujuan pembelajaran yang nantinya akan dikaitkan dengan analisis masalah yang telah dibuat.

6. Langkah 6: Mencari informasi tambahan dari sumber yang lain (diluar diskusi kelompok).

Sudah mengetahui informasi yang belum dimiliki dan sudah menentukan tujuan pembelajaran saatnya mencari informasi tambahan. Keaktifan setiap individu/subkelompok harus terbukti dengan laporan yang disampaikan.

7. Langkah 7: Menggabungkan, menguji informasi baru dan membuat laporan

Dari laporan individu/subkelompok yang dipesentasikan kelompok lain akan mendapat informasi baru serta bertugas sebagai pengkritik yang terkadang menimbulkan pertanyaan- pertanyaan baru yang harus disikapi. Dari langkah-langkah problem based learning dapat digambarkan seperti berikut:

Gambar I Langkah-langkah PBL Sumber: Amir,Taufiq (2010: 27)

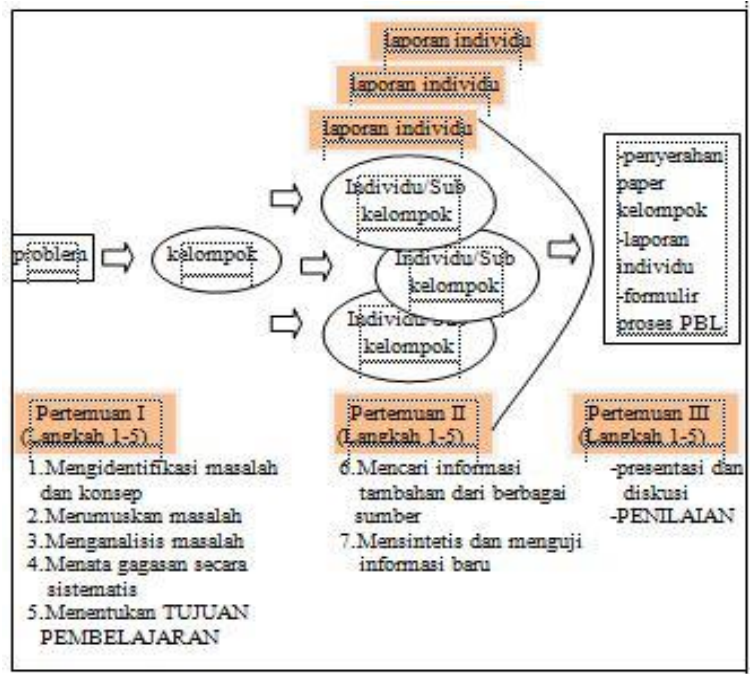

Kelebihan $P B L$ antara lain siswa akan memperluas pengetahuannya selama pembelajaran PKn, sehingga siswa tidak hanya sekedar pada mendengarkan dan mencatat penjelasan dari guru. Siswa juga dilekatkan dengan keterampilan permasalahan nyata bukan hanya sekedar teori, melatih kemampuan bekerjasama melalui kegiatan diskusi kelompok dan mengembangkan kemampuan berpikir kritisnya dalam menyelesaikan permasalahan.

Kelebihan model problem based learning menurut Trianto (2010), yaitu:

1. Dengan PBL akan terjadi pembelajaran bermakna. Siswa yang belajar memecahkan suatu masalah maka mereka akan berusaha mengetahui pengetahuan yang diperlukan. Belajar dapat semakin bermakna dan dapat diperluas ketika siswa berhadapan dengan situasi dimana konsep diterapkan.

2. Dalam situasi PBL, siswa mengintegrasikan pengetahuan dan ketrampilan secara simultan dan mengaplikasikannya dalam konteks yang relevan Artinya, apa yang mereka lakukan sesuai dengan keadaan nyata bukan lagi teoritis. 
3. PBL dapat meningkatkan kemampuan berpikir kritis, menumbuhkan inisiatif siswa dalam bekerja, motivasi internal untuk belajar, dan dapat mengembangkan hubungan interpersonal dalam bekerja kelompok.

Kelemahan $P B L$ haruslah mengangkat isu-isu yang tidak asing lagi bagi siswa sehingga siswa merasa perlu untuk mempelajarinya. Tanpa adanya pemahaman yang baik model pembelajaran ini tidak akan berjalan dengan baik di dalam kelas pembelajaran. Disamping keunggulan problem based learning, Wina Sanjaya (2008) merumuskan kelemahan diantaranya:

1. Manakala siswa tidak memiliki minat atau tidak mempunyai kepercayaan bahwa masalah yang dipelajari sulit untuk dipecahkan, maka mereka akan merasa enggan untuk mencoba.

2. Keberhasilan strategi pembelajaran melalui problem solving membutuhkan cukup waktu untuk persiapan.

3. Tanpa pemahaman mengapa mereka berusaha untuk memecahkan masalah yang sedang dipelajari, maka mereka tidak akan belajar apa yang mereka ingin pelajari.

\section{METODE PENELITIAN}

Jenis penelitian yang digunakan dalam penelitian ini adalah Penelitian Tindakan Kelas (PTK). Menurut Arikunto, Suharsimi (2008: 3), Penelitian tindakan kelas merupakan suatu pencermatan terhadap kegiatan belajar berupa sebuah tindakan, yang sengaja dimunculkan dan terjadi pada sebuah kelas secara bersama. Tindakan tersebut diberikan oleh atau atas arahan dari guru yang kemudian dilakukan oleh siswa. Tahapan yang dilalui dalam PTK, yaitu: a) perencanaan, b) pelaksanaan tindakan, c) pengamatan, d) refleksi. Desain penelitian menggunakan model Kemmis dan Taggart.

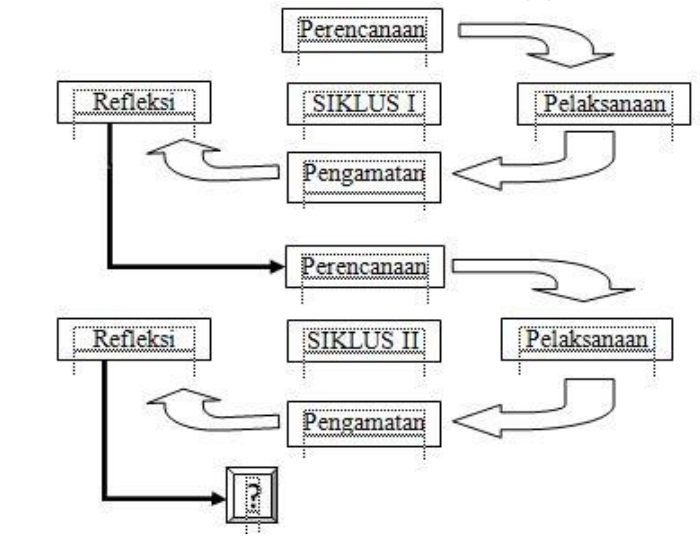

Gambar III

Model Penelitian Kemmis dan Taggart

Sumber: Arikunto, Suharsimi (2010)

Penelitian ini dilakukan di SD Muhammadiyah Kauman Yogyakarta. Pelaksanaan penelitian dilakukan dari bulan April sampai bulan Mei 2017. Subjek penelitian ini adalah seluruh siswa kelas 5 B1 di SD Muhammadiyah Kauman Tahun Ajaran 2016/2017 yang berjumlah 31 siswa. Objek penelitian ini adalah untuk mengetahui keseluruhan proses dan hasil pembelajaran PKn dengan penerapan model Problem Based Learning.

Teknik pengumpulan data yang digunakan dalam penelitian tindakan kelas ini adalah observasi, tes, catatan harian, wawancara. Teknik analisis data pada penelitian ini menggunakan analisis deskriptif kualitatif. Analisis data observasi dan tes diolah dengan menggunakan rumus: 
Keterangan:

$$
N P=\frac{R}{S M} \times 100
$$

$\mathrm{NP}=$ Nilai presentase yang dicari

$\mathrm{R}=$ Skor mentah yang diperoleh siswa

$\mathrm{SM}=$ Skor maksimum ideal

$100=$ Bilangan tetap

(Purwanto, Ngalim 2013: 102)

Kemudian presentase data tersebut dapat ditafsirkan dengan kalimat kualitatif yang mengacu pada tabel berikut:

\section{Tabel 8 Skala Penilaian}

\begin{tabular}{cc} 
Nilai & Keterangan \\
\hline $81-100 \%$ & Baik Sekali \\
\hline $61-80 \%$ & Baik \\
\hline $41-60 \%$ & Cukup \\
\hline $21-40 \%$ & Kurang \\
\hline$<20 \%$ & Kurang Sekali
\end{tabular}

(Arikunto \& Cepi, 2014: 35)

Validitas Instrumen menggunakan validitas konstruk. Sebuah instrumen dikatakan valid apabila mampu mengukur apa yang diinginkan (Arikunto, Suharsimi, 2010: 211). Tenaga ahli untuk mengukur validitas instrumen dalam penelitian ini adalah Suyitno, M.Pd.

Kriteria keberhasilan pada penelitian ini dapat dilihat dari meningkatnya kemampuan berpikir kritis siswa dari siklus I ke siklus selanjutnya yaitu dengan rata-rata hasil lembar observasi dan tes minimal mencapai $61 \%$. Peneliti merencanakan setiap siklus dua kali tatap muka dengan alokasi waktu 2x35 menit. Prosedur penelitian dapat dijelaskan sebagai berikut:

a. Perencanaan (planning)

Perencanaan merupakan tahapan awal dalam penelitian. Adapun tahapannya sebagai berikut:

1. Melakukan observasi awal terhadap situasi dan kondisi kelas saat pembelajaran.

2. Mengumpulkan data siswa.

3. Menyiapkan materi PKn yang akan diajarkan.

4. Menyusun Rencana Pelaksanaan Pembalajaran (RPP) yang akan dilaksanakan sesuai model pembelajaran yang telah ditentukan.

5. Menyusun dan mempersiapkan instrumen penilaian seperti lembar observasi, lembar tes, catatan lapangan, pedoman wawancara dan dokumentasi.

6. Mempersiapkan media dan sumber belajar yang akan digunakan selama pelaksanaan tindakan

7. Melakukan koordinasi dengan guru PKn

b. Pelaksanaan dan Pengamatan (Act And Observe)

Tahap pelaksanaan dilakukan bersamaan dengan pengamatan tindakan. Pada tahap ini peneliti sebagai guru pengajar. Rencana tindakan yang telah dibuat bersifat fleksibel dan 
dapat diubah sesuai dengan keadaan yang ada selama proses pelaksanaan di lapangan. Pelaksanaan tersebut dapat dirinci sebagai berikut:

1) Kegiatan Pendahuluan

(a) Guru membuka pembelajaran dengan mengucapkan salam, kemudian dilanjutkan dengan salah satu siswa memimpin berdoa.

(b)Guru melakukan presensi dan menanyakan bagaimana kabar siswa.

(c) Guru melakukan apersepsi dan motivasi yang mengarah kepada materi pelajaran.

(d)Guru menyampaikan tujuan pembelajaran.

2) Kegiatan Inti

(a) Membagikan name tag dan handout yang berisi permasalahan-permasalahan sesuai dengan materi pelajaran dan dicari solusinya.

(b)Siswa dikondisikan sebelum inti pembelajaran dimulai.

(c) Siswa mendengarkan penjelasan guru mengenai materi pembelajaran dengan media gambar.

(d)Siswa dipandu oleh guru melakukan kegiatan eksplorasi dengan melakukan tanya jawab mengenai materi.

(e) Siswa diarahkan melengkapi bagan gambar secara mandiri.

(f) Siswa dipandu oleh guru melakukan kegiatan elaborasi dengan model pembelajaran berbasis masalah dan menjelaskan langkah-langkahnya.

(g)Siswa dibagi menjadi 6 kelompok kecil yang masing-masing kelompok terdiri dari 4-5 siswa.

(h)Siswa melakukan diskusi dalam kelompok kecil selama 20 menit dengan berbagai sumber.

(i) Siswa melakukan presentasi dan menjelaskan hasil diskusinya didepan kelas.

(j) Siswa difasilitasi kegiatan diskusi kelas dan tanya jawab

(k)Guru memberikan konfirmasi dan penjelasan mengenai hasil diskusi kelompok.

(1) Siswa diberikan evaluasi dengan membagikan soal tes uraian kepada setiap siswa untuk dikerjakan selama 20 menit.

3) Kegiatan Penutup

(a) Siswa bersama guru membuat kesimpulan mengenai materi yang sudah dipelajari.

(b)Guru melakukan refleksi mengenai pembelajaran.

(c) Guru ngulas singkat materi pembelajaran minggu selanjutnya.

(d)Guru menutup pembelajaran dengan mengucap salam.

Bersamaan dengan tahap pelaksanaan, observer melakukan pengamatan terhadap guru, serta kemampuan berpikir kritis belajar siswa dengan mengacu pada lembar observasi dan tes yang telah dibuat sebelumnya.

c. Refleksi (Reflect)

Refleksi dilaksanakan pada tahap akhir dalam penelitian. Catatan tersebut berupa kelebihan/manfaat maupun kekurangan yang terjadi selama proses pembelajaran. Pada tahap ini hasil yang telah dikumpulkan kemudian dianalisis, dan dapat diketahui apakah hasil sudah memenuhi target dan tujuan pembelajaran yang diharapkan dalam penelitian. Jika belum, maka penelitian dilanjutkan ke siklus berikutnya. Pada siklus berikutnya dilakukan rencana tindak lanjut dalam penelitian. Kelebihan atau kekurangan pada tahap I akan diperbaiki pada siklus selanjutnya.

Siklus kedua merupakan kegiatan perbaikan dari Siklus I. Pada siklus ini langkahlangkah yang dilakukan mengikuti siklus sebelumnya. Siklus II bertujuan untuk memperbaiki kekurangan dan hasil yang belum tercapai pada siklus I dan meningkatkan lagi keberhasilan yang telah tercapai. Jika hasil yang diperoleh dari siklus II masih belum 
memenuhi target dan tujuan pembelajaran yang diharapkan, maka penelitian ini akan dilanjutkan ke siklus selanjutnya.

\section{HASIL PENELITIAN DAN PEMBAHASAN}

Penelitian ini telah dilaksanakan pada tanggal 29 April s/d 13 Mei 2017 di SD Muhammadiyah Kauman pada siswa kelas 5 B1 yang berjumlah 31 siswa dengan jumlah 15 siswa laki-laki dan 16 siswa perempuan.

Proses pengambilan data dilaksanakan dengan melakukan penerapan model pembelajaran problem based learning pada mata pelajaran PKn. Sebelum dan sesudah pelaksanaan tindakan dilakukan wawancara terhadap guru sebagai instrumen pendukung menguatkan instrument tes (instrumen utama).

Hasil penelitian menunjukkan adanya peningkatan pada kemampuan berpikir kritis siswa sesuai dengan indikator keberhasilan yang telah ditentukan. Pada Siklus I hasil tes belum menunjukkan keberhasilan pada kemampuan berpikir kritis siswa. Hasil analisis data pada Siklus I masih tergolong cukup dan belum memenuhi kriteria keberhasilan penelitian yaitu dengan hasil baik. Penelitian kemudian dilanjutkan dengan merefleksi hasil Siklus I dan merencanakan penelitian pada Siklus II. Hasil yang diperoleh dari Siklus II menunjukkan adanya keberhasilan penelitian pada setiap indikator yang telah ditentukan. Keberhasilan pada setiap indikator tersebut telah mencapai kriteria baik. Hal tersebut menunjukkan bahwa penelitian tindakan kelas dengan menggunakan model problem based learning telah mencapai keberhasilan. Hasil tes penelitian pada siklus I dan II, dapat dilihat pada grafik berikut:

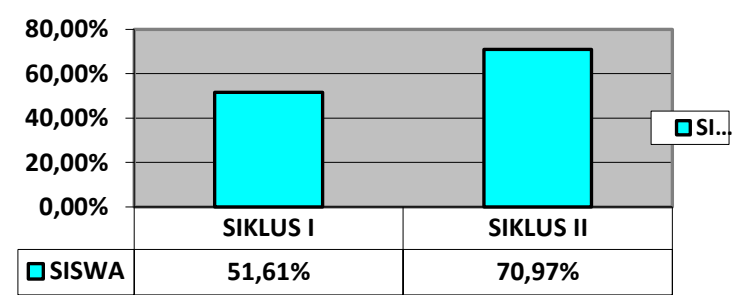

\section{Gambar V Hasil Tes Kemampuan Berpikir Kritis Siswa}

Peningkatan pada aktifitas yang berhubungan dengan kemampuan berpikir kritis siswa juga terlihat pada hasil observasi siswa. Hasil observasi siswa pada siklus I dan II dapat dilihat pada grafik:

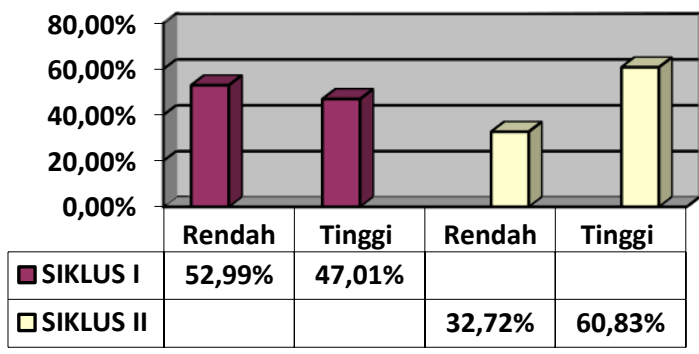

Berdasarklan hasil observasi dan tes tersebut, secara keseluruhan tujuan penelitian tindakan kelas dengan menggunakan model problem based learning telah tercapai pada siklus II, sehingga penelitian ini dianggap sudah berhasil dan selesai pada siklus II.

\section{KESIMPULAN DAN SARAN}

Berdasarkan hasil penelitian dan pembahasan, maka penelitian ini dapat ditarik kesimpulan bahwa penerapan model problem based learning dapat meningkatkan kemampuan berpikir kritis siswa kelas 5 pada mata pelajaran PKn SD Muhammadiyah 
Kauman Tahun Ajaran 2016/2017. Peningkatan kemampuan berpikir kritis pada siswa ditandai dengan meningkatnya rata-rata hasil tes kemampuan berpikir kritis siswa yaitu dari Siklus I ke Siklus II sebesar 51,61 \% menjadi 70,97 \%.

\section{DAFTAR PUSTAKA}

Amir, Taufiq. 2010. Inovasi Pendidikan Melalui Problem Based Learning Bagaimana pendidik Memberdayakan Pembelajar di Era Pengetahuan. Jakarta: Kencana.

Arikunto, Suharsimi dkk. 2008. Penelitian Tindakan Kelas. Jakarta: PT. Bumi Aksara. 2010. Prosedur Penelitian. Jakarta: Rineka Cipta.

Arikunto, Suharsimi \& Cepi, Safruddin Abdul Jabar. 2014. Evaluasi Program Pendidikan. Jakarta: PT. Bumi Aksara.

Bono, Edward De. 2007. Revolusi Berpikir Edward De Bono: Belajar berpikir canggih dan kreatif dalam memecahkan masalah dan memantik ide- ide baru. Bandung: Kaifa.

Daryanto. 2015. Pengelolaan Budaya dan Iklim Sekolah. Yogyakarta: Gava Media.

Fathurrohman. 2008. Pendekatan Pembelajaran Berbasis Masalah Untuk Meningkatkan Kemampuan Berpikir Kritis Siswa SD dalam Pembelajaran PKn. Majalah Ilmiah PembelajaranVolume $4, \quad$ Nomor 1. http://journal.uny.ac.id/index.php/mip/article/view/6879. Diakses 8 November 2016 pukul 22.50.

Huda, Miftahul. 2014. Model-Model Pengajaran Dan Pembelajaran: Isu-Su Metodis Dan Paradigmatis. Yogyakarta: Pustaka Pelajar.

Ngalimun. 2012. Strategi dan Model Pembelajaran. Yogyakarta: Aswaja Pressindo.

Purwanto, Ngalim. 2013. Prinsip-prinsip dan Teknik Evaluasi Pengajaran. Bandung: PT Remaja Rosdakarya.

Sanjaya, Wina. 2008. Strategi Pembelajaran Berorientasi Standar Proses Pendidikan. Jakarta: Kencana Prenada Media Group.

Tim Pusat Studi Pancasila UGM. 2015. Membangun Kedaulatan Bangsa Berdasarkan Nilai-Nilai Pancasila: Pemberdayaan Masyarakat Dalam Kawasan Terluar, Terdepan, dan Tertinggal (3T) (Kumpulan Makalah Call for Papers Kongres Pancasila VII). Yogyakarta: Pusat Studi Pancasila UGM.

Trianto. 2010. Model Pembelajaran Terpadu: Konsep, Strategi, dan Implementasinya dalam Kurikulum Tingkat Satuan Pendidikan (KTSP). Jakarta: PT. Bumi Aksara.

Wahyuni, Sri. 2011. Mengembangkan Keterampilan Berpikir Kritis Siswa Melalui Pembelajaran IPA Berbasis Problem Based Learning. Seminar Nasional FMIPA-UT 2011. Diakses 2 Januari 2017 pukul 22.32. 